\section{Supply of Vitamins in Soviet Russia}

Prof. P. V. Golovin, president of the Vitamins Council of the Soviet Commissariat of the Food Industry, has recently stated that whereas the antiscurvy vitamin $\mathrm{C}$ used previously to be manufactured from conifers, it is now being made from the sweet briar rose. Vitamin $\mathrm{C}$ is mainly used by people living in the north and in the Arctic. In 1935 three million doses of this vitamin were manufactured in Soviet Russia, and in 1936 thirteen million doses would be turned out. Confectionery factories are now producing caramels, sugar plums and jellied sweets containing vitamin $\mathrm{C}$. Two vitamin factories have been constructed in Leningrad and Schnelkovo. In the latter place a vitamin combine is being built which would produce vitamin $\mathrm{A}$ in addition to vitamin $\mathrm{C}$. In Moscow a factory has been built for the manufacture of anti-rickets vitamin $\mathrm{D}$ obtained from yeast.

\section{Announcements}

Sir Albert SEWARd, formerly professor of botany in the University of Cambridge, was elected an honorary member of the New York Academy of Sciences at its annual meeting held on December 21.

LoRD Swinton, Secretary of State for Air, has appointed Dr. D. R. Pye to be director of scientific research in the Department of the Air Member for Research and Development, Air Ministry, on the retirement of Mr. H. E. Wimperis, and Mr. W. S. Farren to be deputy director of scientific research in succession to Dr. Pye.

Dr. E. Neaverson has been awarded the Medal of the Liverpool Geological Society. Dr. Neaverson, who is senior lecturer (palæontology) in the Department of Geology of the University of Liverpool, is well known for his work on the Carboniferous rocks of North Wales and the Quaternary beds of the Rhyl district. Farther afield, he has carried out research on the bottom-deposits collected on the voyages of the R.R.S. Discovery. $\mathrm{He}$ is a past president of the Liverpool Geological Society.

THE following appointments have recently been made to the Colonial Service: A. C. E. Callan, produce inspector, Agricultural Department, Zanzibar; W. K. Hubble, principal, Kadoorie Arab Agricultural School, Tulkarm, Palestine ; G. F. Clay, (deputy director of agriculture, Uganda), assistant director of agriculture, Nigeria; W. F. Jepson, (Phytalus investigator), entomologist, Agricultural Department, Mauritius; H. Macluskie (agricultural superintendent, British Guiana), agricultural officer, Sierra Leone.

IT is announced in Science that, following the Harvard tercentenary, the French Government has conferred membership in the Legion of Honour with the rank of commander on President J. B. Conant. Prof. George D. Birkhoff, Prof. Julian L. Coolidge, Prof. James B. Munn and Jerome D. Green, director of the tercentenary, have been promoted from the rank of chevalier to that of officer of the legion. The rank of chevalier has been conferred on Profs. Bliss Perry, Edward B. Hill, Edward W. Forbes, Roger Bigelow Merriman, Ralph Barton Perry, Edward A. Whitney, Kenneth J. Conant and George H. Edgell.

THE one hundredth and fifth annual meeting of the British Medical Association will be held in Belfast, commencing on July 16. The president-elect is Prof. R. J. Johnstone, professor of gynæcology in Queen's University, Belfast.

THE Faraday Society will hold a general discussion on "The Properties and Functions of Membranes, Natural and Artificial", on April 22-24, at University College, Gower Street, London, W.C.1. Another discussion on "Reaction Kinetics" will be held in the University of Manchester on September 13-15. As is usual at these general discussions, contributions will be made by a number of foreign men of science. Further information can be obtained from the Secretary, Faraday Society, I3 South Square, Gray's Inn, W.C.1.

A series of eight lectures on "The Economic Problem and World Peace" to be given in the Essex Hall, Strand, London, W.C.1, during February and March has been arranged by the National Peace Council. The first lecture, on February 8, was given by Graham Hutton on "The Continental Western Democracies". Subsequent lectures cover "The Small Countries of Central and South-Eastern Europe" (T. Balogh); Germany (B. Thomas); Italy (H. Fines); the Soviet Union (L. Segal); Japan and China (F. Utley); the United States (H. Quigley) and the British Empire (H. V. Hodson). The lectures are to be given on Mondays at 6.15 and tickets (4s. for the course) and other particulars can be obtained from Mr. G. Bailey, National Peace Council, 39 Victoria Street, S.W.I.

THE Rockefeller Foundation has recently given 9,000 Swiss francs to the University Psychiatric Clinic at Bern for the orection of a laboratory for investigation of the anatomy of the brain.

NoRway has introduced a regulation by which no professional motor-driver may consume any alcoholic beverage while driving or during the previous eight hours. In suspected cases a blood test is carried out, when, if the blood has an alcohol content of more than 0.5 per mille, the law will be considered to have been broken.

IN the letter entitled "Equivalent Particle Observers" by Prof. Leigh Page in Nature of January 16, p. 111, the first sentence of the second paragraph should read: "My approach to the relativistic kinematics differs from Milne's in that I employ the concept of equivalence to establish reference systems consisting of dense aggregates of synchronous particle-observers relatively at rest". 